\title{
Incentive Function of Audit Opinion for the Increase of Regional Operational Expenditure and Own-Source Revenues Through Sensitivity Analysis in Indonesia
}

\author{
Muhammad Ikbal Abdullah ${ }^{1}$, Andi Chairil Furqan ${ }^{1}$, Nina Yusnita Yamin ${ }^{1} \&$ Fahri Eka Oktora ${ }^{2}$ \\ ${ }^{1}$ Universitas Tadulako, Palu, Indonesia \\ ${ }^{2}$ Sekolah Tinggi Ilmu Ekonomi (STIE) Mujahidin Tolitoli, Indonesia \\ Correspondence: Andi Chairil Furqan, Universitas Tadulako, Palu, Indonesia.
}

Received: December 16, 2019

Accepted: January 22, 2020

Online Published: March 5, 2020

doi:10.5430/rwe.v11n1p20

URL: https://doi.org/10.5430/rwe.v11n1p20

\begin{abstract}
This study aims to analyze the sensitivity testing using measurements of realization of regional own-source revenues and operating expenditure and to analyze the extent of the effect of sample differences between Java and non-Java provinces by using samples outside of Java. By using sensitivity analysis, the results found the influence of audit opinion on the performance of the provincial government mediated by the realization of regional operating expenditure. More specifically, when using the measurement of the absolute value of the realization of regional operating expenditure it was found that there was a direct positive and significant influence of audit opinion on the performance of the Provincial Government. However, no significant effect of audit opinion was found on the realization value of regional operating expenditure and the effect of the realization value of regional operating expenditure on the performance of the Provincial Government. This result implies that an increase in audit opinion will be more likely to be used as an incentive for the Provincial Government to increase the realization of regional operating expenditure.
\end{abstract}

Keywords: legitimacy theory, audit opinion, operational expenditures, own-source revenues, sensitivity analysis

\section{Introduction}

Audit opinion on regional government financial statements is assumed to function as the basis of legitimacy provided by parties with an interest in the regional government, especially the local community (Power, 2003; Din et al., 2017; Suwanda, 2015; Gaspar \& Mkasiwa, 2015). The synchronization between audit opinion with the expectations of the community will have an impact on increasing community resources given to the regional government, especially in the form of regional taxes and regional retribution. Hence, audit opinion has a positive effect on achieving realization regional government revenues, especially regional own-source revenue. Auditing henceforth serves to provide public trust in the fairness of the presentation of financial statements in describing the actual economic activity (Dye, 2007).

Based on Law Number 15 of 2004 concerning the Audit of Management and Responsibility of State Finances, the Supreme Audit Board (BPK) has the role of an external auditor of the government, which has freedom and independence in the three stages of the audit, namely planning, implementation, and reporting of audit results. Inspections conducted by the BPK may take the form of financial audits, performance audits and audits with specific objectives. In particular, financial audits are conducted in the context of providing opinions on the level of reasonableness of the information presented in the government financial statements. Opinion is an examiner's professional statement regarding the reasonableness of financial information presented in government financial statements (Pamungkas et al., 2018). Related to the role of audit opinions, Power (2003) states that audit opinions must be clean to be consumed by outsiders, so that they can be the basis for users of financial statements in determining financial management performance, particularly in local governments. In addition, in order to realize transparency and public participation, based on applicable laws and regulations, the inspection report that has been submitted to the legislature or in this case the national or local parliaments is declared open to the public and obliged to be published to the public both through the media printed or electronic. With this publication, it is expected that the public can assess the extent of the management of state/regional finances carried out by the government and at the same time be able to assess the performance of the government in general, particularly in regional governments. 
Previous studies show that the realization of income affects the performance of the regional government (Mustikarini and Fitriasari, 2012; Marfiana and Kurniasih, 2013; Abdullah et al., 2019). This indicates that the realization of regional income can be a mediator of the influence of audit opinion on the performance of the regional government. This study provides new empirical evidence related to the mediation variable on the influence of audit opinion on performance in the form of variable levels of achievement of the realization of regional income and expenditure that the author's knowledge has never been done by previous research. The results of this study indicate that the realization of regional own-source revenue is mediating the effect of audit opinion on the performance of local government. Power (2003) and Ferraz \& Finan (2008), Susilo (2018), Kurniawan (2017) showed that audit opinion has functioned as a tool to increase community legitimacy to the regional government, so that the better opinion of the Regional Government audit will have a positive and significant impact on the achievement of the realization of own-source revenue. Mustikarini and Fitriasari (2012) found that the increased realization of the own-source revenue has an impact on the increasing performance of the Regional Government. Hence, this study aims to analyze the sensitivity testing using different measurements related to the realization of regional own-source revenues and operating expenditure and to analyze the extent of the effect of sample differences between Java and non-Java provinces, sensitivity testing was carried out by only using samples outside of Java.

\section{Literature Review and Hypothesis}

Audit opinion reflected the performance of government and can also be used to legitimize the government (Holm \& Zaman, 2012; Whittle et al., 2014; Goddard \& Issa Mzenzi, 2015; Gabrini, 2013; Colquhoun, 2011). Simply, when the audit opinion is in line with the expectations of the community, it will have an impact on increasing community resources given to the regional government, especially in the form of regional taxes and regional retribution. Audit opinion has a positive effect on achieving realization regional government revenues, especially regional own-source revenue. The basic assumption of the theory of legitimacy as stated by Suchman (1995) is that legitimacy to the organization will be formed when there are conditions of organizational behavior that are in line with the expectations of the parties around the organization carrying out its activities. When legitimacy to the organization is reduced, it will have consequences on the reduced flow of resources received and have a negative impact on the achievement of organizational goals (see, Deephouse \& Suchman, 2008; Bitektine, 2011). Therefore, it is important for organizations to design and manage organizational institutions in order to protect or maintain legitimacy (Gabrini, 2013). This is also in line with the statement of Power (2003) which states that with the increasing demands for transparency and accountability of organizations today, the audit plays an important role in producing legitimacy.

Furthermore, the results of previous studies (Mustikarini and Fitriasari, 2012; Marfiana and Kurniasih, 2013) show that the realization of revenue affects the performance of the regional government. This indicates that the realization of regional income can be a mediator of the influence of audit opinion on the performance of the regional government. Budianto (2012) used a sample of 1,082 district/city governments in Indonesia for the period 2008-2010 found that audit opinions and other variables such as gender of regional government leaders, total regional own source revenue and regional assets has a positive and significant effect on the performance of the regional government as measured by the performance evaluation rating of the regional government performance, while the audit findings from the Audit Board of Indonesia have a negative and significant effect on the performance of the regional government. Although using different samples, the results of this study are in line with the results of the Asmoko (2015) study which found that in the context of State Ministries and Institutions during the 2011-2013 period, there was no significant relationship between the Audit Board of Indonesia audit opinion on Financial Statements of ministries and state institutions and the results of evaluation on State Ministries and Institutions.

By considering the magnitude of the needs of the regional government towards the legitimacy of the community and the government in supporting the implementation and financing of regional development programs, the regional government will always strive to increase its credibility, especially related to the management of regional finances marked by the achievement of good audit opinion (Furqan \& Din, 2019). Schneider and Damapour (2002) found a positive relationship between reporting quality financial planning of pension funds, the results of this study also show that audit opinion has a positive and significant effect on the realization of operating expenditures, and as the results of Mustikarini and Fitriasari (2012) research, operating expenditure has a negative and significant effect on the performance of the Regional Government. Schneider and Damapour (2002) and Giroux and Shields (1993) revealed the positive and negative effects of financial reporting quality on public expenditure as explained by public choice theory and the difference between the results of Marfiana and Kurniasih (2013) with Mustikarini and Fitriasari (2012) who each found a positive and negative influence on regional expenditure on the performance of local governments, where the differences in the results of these studies are likely to be caused by differences in measurement of the public expenditure/area used and including differences in the sample used. 
Suchman (1995) states that the legitimacy of the organization will be formed when there are conditions of organizational behavior that are in line with the expectations of the parties around the organization carrying out their activities. When there is a mismatch between the expectations of the parties around the organization's achievements will result in reduced legitimacy of the organization, which can have an impact on the reduced flow of resources received by the organization and have a negative impact on achieving organizational goals, and vice versa. Therefore it is important for organizations to design and manage organizational institutions in order to protect or maintain legitimacy (Gabrini, 2013). In order to increase the legitimacy of the Government and the community towards the Regional Government, if based on Power (2003) which states that with the increasing demands for transparency and accountability of the current organization, the audit plays an important role in producing the legitimacy and research results of Ferraz \& Finan (2008) who found the effect of the audit results on corruption in the Regional Government on the re-election of the incumbent can be said that the existence of an audit opinion will be one of the determinants for the creation of the legitimacy of the Government and the Community. When an audit opinion on financial statements can illustrate high accountability for the management of resources carried out by the Regional Government, this will encourage the community to increase the resources provided to the Regional Government, which is realized by increasing the achievement of the realization of regional revenues, especially those sourced from from the community in the form of regional own-source revenues.

Therefore, the hypothesis can be formulated that audit opinion has a positive effect on the achievement of realization of regional original income $(\mathrm{H} 1)$, and audit opinion influences the realization of regional operating expenditure $(\mathrm{H} 2)$.

\section{Method}

This study uses data from 32 provincial governments with the sample divided into two groups, namely the sample group as a whole as many as 150 observations (province-year) and the sample group only for provinces outside Java as many as 130 observations (province-year) during the period of years 2010-2014. To test the sensitivity of influence outside of Java, the sample is dominated by provinces outside of Java as many as 130 provinces or 86.67 percent and the remaining 20 observations or 13.33 percent are data from provinces on Java. The sensitivity testing using different measurements related to the realization of regional own-source revenues and operating expenditure, namely by using the absolute value of regional own-source revenue and realization of regional expenditure in the form of natural logarithms (Ln). Data analysis was performed using STATA-12 analysis tools.

\section{Results}

\subsection{Sensitivity Testing}

First test is to measure sensitivity by using the value of realization of regional own-source revenues and operational expenditures. To examine the extent of the effect of the measurement differences, the analysis was conducted sensitivity testing using the absolute value of regional own-source revenue realization and regional operating expenditure as the results can be seen in Table 1.

Table 1. Sensitivity results using regional own-source revenues and operational expenditures

\begin{tabular}{|c|c|c|c|c|c|}
\hline \multirow{2}{*}{ Variable } & \multirow{2}{*}{ Sign } & \multirow{2}{*}{$\begin{array}{l}\text { Direct } \\
\text { Influence } \\
(\text { PERF) }\end{array}$} & \multicolumn{3}{|c|}{ Indirect Effects } \\
\hline & & & LnREV & LnOPER & PERF \\
\hline Intercept & & $\begin{array}{l}9.497 \\
(0.567)\end{array}$ & $\begin{array}{l}-4.035^{* * *} \\
(0.0000\end{array}$ & $\begin{array}{l}2.201 * * * \\
(0.002)\end{array}$ & $\begin{array}{l}148.318^{* *} \\
(0.019)\end{array}$ \\
\hline Opinion & + & $\begin{array}{l}2.497 * * * \\
(0.000)\end{array}$ & $\begin{array}{l}0.196 * * * \\
(0.000)\end{array}$ & $\begin{array}{l}0.054 * \\
(0.066)\end{array}$ & - \\
\hline LnREV & + & $\begin{array}{l}6.055^{* * * *} \\
(0.000)\end{array}$ & - & - & $\begin{array}{l}26.096^{* * * *} \\
(0.004)\end{array}$ \\
\hline LnOPER & $+/(-)$ & $\begin{array}{l}0.621 \\
(0.737)\end{array}$ & - & - & $\begin{array}{l}-25.705^{* *} \\
(0.019)\end{array}$ \\
\hline Ln_ASSET & $?$ & $\begin{array}{l}-2.328 \\
(0.215)\end{array}$ & $\begin{array}{l}0.951 * * * \\
(0.0000\end{array}$ & $\begin{array}{l}0.813 * * * \\
(0.000)\end{array}$ & - \\
\hline HDI & $?$ & 0.107 & $0.033 * *$ & $-0.025^{* * *}$ & $-1.236 * *$ \\
\hline
\end{tabular}




\begin{tabular}{|c|c|c|c|c|c|}
\hline \multirow{3}{*}{ ISLAND } & & $(0.583)$ & (0.019) & $(0.003)$ & $(0.049)$ \\
\hline & $?$ & 1.403 & $-0.543 * * *$ & $-0.226 * *$ & 6.321 \\
\hline & & $(0.591)$ & $(0.000)$ & $(0.025)$ & $(0.201)$ \\
\hline Observation & & 150 & 150 & 150 & 150 \\
\hline Prob. $>$ F/chi ${ }^{2}$ & & $0.000 * * *$ & $0.000 * * *$ & $0.000 * * *$ & $0.000^{* * *}$ \\
\hline Adj. R-Squared & & - & 74.17 & 78.73 & - \\
\hline Wald Chi2 & & 17.45 & - & - & 32.74 \\
\hline
\end{tabular}

$P E R F$, is Local Government Performance, which is measured by the score of the evaluation results on the Government Institution Performance Accountability System (SAKIP) year t; OPINION, is the audit opinion on the previous year's LKPD (t-1), which is measured categorically, namely "5" for Unqualified Opinion, "4" for Unqualified Opinion with Explanatory Paragraph, "3" for Qualified Opinion, "2" for Adversed Opinions, and "1" for Disclaimer; LnREV is the amount of Regional Original Revenue, which is measured by the natural logarithm of the absolute value of the total regional income in the year $t$; LnOPER is the amount of Regional Operational Expenditures, which is measured by the natural logarithm of total operating expenses for the year t; Ln_ASSET is the Regional Total Asset, measured by the natural logarithm of the absolute value of the total assets of the year t, the HDI is the Human Development Index, which is measured by the area development index score of the year $t$; and ISLAND is the location of the province, measured by dummy variables, namely " 1 " for provinces outside Java and other "0".

$* * *, * *, *=P$-value significant at $1 \%, 5 \%, 10 \%$.

Table 1 presents the results of sensitivity testing using different measurements related to the realization of regional own-source revenues and operating expenditure, namely by using the absolute value of regional own-source revenue and realization of regional expenditure in the form of natural logarithms (Ln). By using the absolute value of regional own-source revenue and realization of regional expenditure, the results show that consistent with the results of testing in table 4, it was found that both mediated and not mediated by the realization of regional own-source revenue, audit opinion has a positive and significant effect on the performance of the Provincial Government. Besides the direct relationship, determinant factors and the role of mediating variable of regional own-source revenue are also consistent between the two measurements. However, related to the role of mediation in the realization of regional expenditures, the results of this sensitivity test are somewhat different from the results of the tests. Table 5 showed that the value of regional operating expenditure does not have a significant direct effect on the performance of the Provincial Government, but when it is tested the mediating role of regional operating expenditure, it is found that audit opinion has a positive and significant effect on the realization of regional operating expenditures with a coefficient of 0.054 , and then realization of expenditure regional operations have a negative and significant effect on the performance of the Provincial Government. This result can be interpreted that when the previous year's audit opinion was an incentive for the provincial government to increase the realization of regional operating expenditure, the increase could have a negative impact on the performance of the provincial government.

The results of the study differ from Budianto (2012) in a study by using a sample of 1,082 district/city governments in Indonesia for the period 2008-2010 which found that audit opinions and other variables such as gender of regional government leaders, total regional own source revenue and regional assets has a positive and significant effect on the performance of the regional government as measured by the performance evaluation rating of the Regional Government performance, while the audit findings from the Audit Board of Indonesia have a negative and significant effect on the performance of the regional government. The results is also consistent with the results of overall sample testing, only using samples from provincial governments outside Java. Positive and significant effect on the performance of the provincial government, but when functioning as a mediator, the level of percentage of regional operating expenditure is not affected by audit opinion and also does not affect the performance of the provincial government. By using absolute value measurements, the amount of regional operating expenditure has a positive and significant effect on the performance of the provincial government. However, as a mediator, the percentage of regional operating expenditure is not affected by audit opinion and also does not affect the performance of the provincial government. The results of this sensitivity test are somewhat different when using measurements of the absolute value of realization of regional operating expenditure, because it was found that although the previous year's audit opinion did not affect the realization of regional operating expenditure, the realization of regional expenditure had a negative and significant effect on performance. 
Furthermore, related to the mediating role of expenditure realization, the results of this study show different results when using different measurements. The test conducted by using absolute value measurements showed that operating expenditure does not have a significant direct effect on the performance of the Provincial Government, but when mediating the effect of audit opinion on the performance of the Provincial Government. The results of this sensitivity test provide evidence that the possibility of different results due to differences in the measurement of regional expenditure realization, so that in addition to providing additional explanations for the results of this study as a whole, these results can also answer the possible causes the difference between the results of Schneider and Damapour (2002) with Giroux and Shields (1993) related to the positive and negative effects of financial reporting quality on public expenditure as explained by public choice theory and the difference between the results of Marfiana and Kurniasih's research (2013) with Mustikarini and Fitriasari (2012) who each found a positive and negative influence on regional expenditure on the performance of local governments, where the differences in the results of these studies are likely to be caused by differences in measurement of the public expenditure/area used and including differences in the sample used.

\subsection{Sensitivity Results of Samples Outside of Java}

Previous studies on the comparison between samples of the provincial government on Java and outside Java found that there were differences in performance, audit opinion, absolute value of regional own-source revenue, percentage of revenue, absolute value of regional expenditure, HDI score and significant asset value between the provincial government outside the island of Java compared to the provincial government on the island of Java (see for instance, Gamayuni, 2016; Martani \& Fitriasari, 2014; Suranta et al., 2018; Akbar et al., 2012). Therefore, to analyze the extent of the effect of sample differences on the results of this study, sensitivity testing was carried out by only using samples outside of Java. In addition, in the second sensitivity test it was re-tested whether there were differences in results if using different measurements as shown in previous tests. The results of sensitivity testing which only uses samples outside Java Island using measurements of absolute values \& the percentage of regional own-source revenue realization and regional operating expenditure are presented in Table 2.

Table 2. Sensitivity results of samples outside of Java using measurements of absolute value \& percentage

\begin{tabular}{|c|c|c|c|c|c|c|c|c|c|}
\hline \multirow{3}{*}{ Variable } & \multirow{3}{*}{ Sign } & \multicolumn{4}{|l|}{ Percentage } & \multicolumn{4}{|c|}{ Absolute value } \\
\hline & & \multirow{2}{*}{$\begin{array}{l}\text { Direct } \\
\text { Influence } \\
(\mathrm{PER})\end{array}$} & \multicolumn{3}{|c|}{ Indirect Effects } & \multirow{2}{*}{$\begin{array}{l}\text { Direct } \\
\text { Influence } \\
\text { (PERF) }\end{array}$} & \multicolumn{3}{|c|}{ Indirect Effects } \\
\hline & & & P_REV & P_OPER & PERF & & Ln_REV & Ln_OPER & PERF \\
\hline Intercept & $?$ & $\begin{array}{l}-33.397 * \\
(0.088)\end{array}$ & $\begin{array}{l}-96.344 * * * \\
(0.000)\end{array}$ & $\begin{array}{l}135.239 * * * \\
(0.000)\end{array}$ & $\begin{array}{l}71.463 \\
(0.383)\end{array}$ & $\begin{array}{l}14.589 \\
(0.364)\end{array}$ & $\begin{array}{l}-4.928 * * * \\
(0.000)\end{array}$ & $\begin{array}{l}1.917 * * * \\
(0.005)\end{array}$ & $\begin{array}{l}123.059 * * * \\
(0.008)\end{array}$ \\
\hline Opinion & $+/(-)$ & $\begin{array}{l}2.678 * * * \\
(0.000)\end{array}$ & $\begin{array}{l}3.281 * * * \\
(0.006)\end{array}$ & $\begin{array}{l}0.500 \\
(0.477)\end{array}$ & & $\begin{array}{l}2.148 * * * \\
(0.001)\end{array}$ & $\begin{array}{l}0.200 * * * \\
(0.000)\end{array}$ & $\begin{array}{l}0.036 \\
(0.220)\end{array}$ & - \\
\hline P_REV & + & $\begin{array}{l}0.238 * * * \\
(0.000)\end{array}$ & - & - & $\begin{array}{l}1.081 * * \\
* \\
(0.000)\end{array}$ & - & - & - & - \\
\hline P_OPER & $?$ & $\begin{array}{l}0.286^{* * * *} \\
(0.002)\end{array}$ & & & $\begin{array}{l}0.111 \\
(0.879)\end{array}$ & - & - & - & - \\
\hline Ln_REV & + & - & - & - & - & $\begin{array}{l}7.034 * * * \\
(0.000)\end{array}$ & - & - & $\begin{array}{l}21.342 * * * \\
(0.001)\end{array}$ \\
\hline $\begin{array}{l}\text { Ln_OPE } \\
\mathrm{R}\end{array}$ & $?$ & - & - & - & - & $\begin{array}{l}1.233 \\
(0.521)\end{array}$ & - & - & $\begin{array}{l}-18.556^{* *} \\
(0.013)\end{array}$ \\
\hline $\begin{array}{l}\mathrm{Ln} \_ \text {ASSE } \\
\mathrm{T}\end{array}$ & $?$ & $\begin{array}{l}4.033 * * * \\
(0.000)\end{array}$ & $\begin{array}{l}4.295^{* *} \\
(0.011)\end{array}$ & $\begin{array}{l}-2.362 * * \\
(0.027)\end{array}$ & - & $\begin{array}{l}-2.815 \\
(0.140)\end{array}$ & $\begin{array}{l}0.886 * * * \\
(0.000)\end{array}$ & $\begin{array}{l}0.782 * * * \\
(0.000)\end{array}$ & \\
\hline HDI & $?$ & $\begin{array}{l}0.192 \\
(0.360)\end{array}$ & $\begin{array}{l}1.202 * * * \\
(0.000)\end{array}$ & $\begin{array}{l}-0.706^{* * * *} \\
(0.001)\end{array}$ & $\begin{array}{l}-0.944 * \\
(0.081)\end{array}$ & $\begin{array}{l}-0.026 \\
(0.892)\end{array}$ & $\begin{array}{l}0.046^{* * * *} \\
(0.001)\end{array}$ & $\begin{array}{l}-0.019 * * \\
(0.024)\end{array}$ & $\begin{array}{l}-1.089 * * \\
(0.024)\end{array}$ \\
\hline Observatior & & 130 & 130 & 130 & 130 & 130 & 130 & 130 & 130 \\
\hline
\end{tabular}




$\begin{array}{lllllllll}\text { Prob. }>\text { F/chi } & \\ & 0.000^{* * *} & 0.000^{* * *} & 0.000^{* * *} & 0.000^{* * *} & 0.000^{* * *} & 0.000^{* * *} & 0.000^{* * *} & 0.000^{* * *} \\ \text { Adj. } \text { R-Squared } & - & 15.81 & 7.49 & - & - & 63.14 & 72.25 & - \\ \text { Wald Chi2 } & 18.66 & - & - & 23.43 & 44.25 & - & - & 32.08\end{array}$

$P E R F$, is Local Government Performance, which is measured by the score of the evaluation results on the Government Institution Performance Accountability System (SAKIP) year t; Opinion, is the audit opinion on the previous year's LKPD (t-1), which is measured categorically, namely "5" for Unqualified Opinion, "4" for Unqualified Opinion with Explanatory Paragraph, "3" for Qualified Opinions, "2" for Adversed opinions, and "1" for Disclaimer; LnREV is the amount of Regional Original Revenue, which is measured by the natural logarithm of the absolute value of the total regional income in the year $t$; $P$ REV is the percentage of Regional Original Income, which is measured by the amount of regional revenue divided by the total regional income for the year $t$; LnOPER is the amount of Regional Operational Expenditures, which is measured by the natural logarithm of total operating expenses for the year $\mathrm{t}$; P_OPER is the percentage of regional operating expenditure, which is measured by the amount of regional operating expenditure divided by total regional expenditure in year t; Ln_ASSET is the Regional Total Asset, which is measured by the natural logarithm of the absolute value of the total assets of the year t, the HDI is the Human Development Index, which is measured by the area development index score of the year $\mathrm{t}$.

$* * *, * *, *=P$-value significant at $1 \%, 5 \%, 10 \%$.

Table 2 presents the results of sensitivity testing using a sample of provincial governments outside Java. The results of testing of samples of provincial governments outside Java are consistent with the results of testing of the sample of provincial governments as a whole. The two measurements used, directly on the previous year's audit opinion have a positive and significant effect on the performance of the provincial government. Likewise if it is mediated by the realization of regional own-source revenue, the previous year's audit opinion has a positive and significant effect on the realization of regional own-source revenue, and the realization of regional own-source revenue has a positive and significant effect on the performance of the Provincial Government.

On the other hand, with the increasing quality of provincial government financial reporting, both the local parliament and the Audit Board of Indonesia must also be more careful in carrying out supervision and inspection, especially on regional operating expenditure, because even though the results of this study show mixed results on the two measurements used. However, there are indications that in the better audit opinion in the previous year, there was a tendency to be an incentive for the Provincial Government to further increase the value of regional operating expenditures in the following year, which if this was not monitored closely, it could cause a decrease in Government performance.

\section{Conclusion}

Auditing serves to provide public trust in the fairness of the presentation of financial statements in describing the actual economic activity. In many cases, audit opinion has served as a tool to increase the legitimacy of the community towards the regional government. Better opinion of the regional government audit will have a positive and significant effect on the achievement of budget realization. Furthermore, increasing the realization of the regional budget had an impact on the increasing performance of the regional government. This shows that audit opinion functions can be used as government legitimacy, in addition to its main function for transparency and openness of financial reports.

The results found the influence of audit opinion on the performance of the provincial government mediated by the realization of regional operating expenditure. More specifically, when using the measurement of the absolute value of the realization of regional operating expenditure it was found that there was a direct positive and significant influence of audit opinion on the performance of the Provincial Government. However, no significant effect of audit opinion was found on the realization value of regional operating expenditure and the effect of the realization value of regional operating expenditure on the performance of the Provincial Government. Conversely, when using the measurement of the percentage of realization of regional operating expenditure over total regional expenditure, no significant direct effect of audit opinion was found on the performance of the Provincial Government. However, it was found that there was a significant positive effect of audit opinion on the value of realized regional operating expenditure and the significant negative effect of the value of realized regional operating expenditure on the performance of the provincial government. These results then indicate that the interpretation of the mediating role of the realization of regional operating expenditures on the influence of audit opinion on the performance of the provincial government must be done carefully, because there are differences in results resulting from different 
measurements and samples. Moreover, the results are consistent for the two measurements of own-source revenue (absolute value of own-source revenue and percentage of own-source revenue of total revenue) and two sample groups (the sample as a whole and the sample is limited to the provincial government outside of Java) used in this study.

This result implies that an increase in audit opinion will be more likely to be used as an incentive for the provincial government to increase the realization of regional operating expenditure. When the increase in the value of the realization of the regional expenditure increases due to an increase in audit opinion, it can cause a decrease in the performance of the Provincial Government.

The limitation of this study is that it only uses different measurements of the realization of regional own-source revenues and regional operating expenditures, but has not further analyzed the effect of different measurements of other variables on the results of this study. Further research is expected to add other control variables in the research model, for example the characteristics of regional leaders (governors/regents/mayors), cultural, economic, political factors, the quality of apparatus and supervision by the regional parliament in each Regional Government.

\section{References}

Abdullah, M. I., Furqan, A. C., Parwati, N. M. S., \& Asmanurhidayani. (2019). The effect of public share ownership on tax evasion: Study on companies listed in Indonesia stock exchange between 2008-2011. International Journal of Financial Research, 10(6), 124-132.

Akbar, R., Pilcher, R., \& Perrin, B. (2012). Performance measurement in Indonesia: the case of local government. Pacific Accounting Review, 24(3), 262-291.

Asmoko, H. (2015). Korelasi Opini Audit BPK atas LKKL dengan Hasil Evaluasi Lakip K/L. L, Balai Diklat Kepemimpinan, BPPK Kementerian Keuangan, Jakarta.

Bitektine, A. (2011). Toward a theory of social judgments of organizations: The case of legitimacy, reputation, and status. Academy of Management Review, 36(1), 151-179.

Budianto, W. (2012). Pengaruh Opini, Temuan Audit Dan Gender Terhadap Kinerja Penyelenggaraan Pemerintah Daerah Kabupaten/Kota Di Indonesia Tahun 2008-2010. FE UI. Depok.

Colquhoun, P. (2011). The production of legitimacy in New Zealand local government auditing. Available at SSRN 2028743.

Deephouse, D. L., \& Suchman, M. (2008). Legitimacy in organizational institutionalism. The Sage Handbook of Organizational Institutionalism, 49, 77.

Din, M., Ghozali, I., \& Achmad, T. (2017). The Follow Up of Auditing Results, Accountability of Financial Reporting and Mediating Effect of Financial Loss Rate: An Empirical Study in Indonesian Local Governments. European Research Studies, 20(4A), 443-459.

Dye, K. M. (2007). Corruption and fraud detection by public sector auditors. EDPAC: The EDP Audit, Control, and Security Newsletter, 36(5-6), 6-15.

Ferraz, C., \& Finan, F. (2008). Exposing corrupt politicians: the effects of Brazil's publicly released audits on electoral outcomes. The Quarterly Journal of Economics, 123(2), 703-745.

Furqan, A. C., \& Din, M. (2019). Social perception on corruption and its influence on public legitimacy and open government (Indonesia). Espacios, 40(13).

Gabrini, C. J. (2013). The effect of internal audit on governance: Maintaining legitimacy of local government. Dissertations, The Florida State University.

Gamayuni, R. R. (2016). The effect of local government characteristics and the examination result of Indonesian supreme audit institution on economic growth, with financial performance as intervening variable in district and city government of lampung province. Research Journal of Finance and Accounting, 7(18), 119-136.

Gaspar, A. F., \& Mkasiwa, T. A. (2015). Managing performance or legitimacy? A case study of the Tanzanian Local Government Authorities. Journal of Accounting in Emerging Economies, 5(4), 424-456.

Giroux, G., \& Shields, D. (1993). Accounting controls and bureaucratic strategies in municipal government. Journal of Accounting and Public Policy, 12(3), 239-262. 
Goddard, A., \& Issa Mzenzi, S. (2015). Accounting practices in Tanzanian local government authorities: towards a grounded theory of manipulating legitimacy. In The Public Sector Accounting, Accountability and Auditing in Emerging Economies (pp. 109-142). Emerald Group Publishing Limited.

Holm, C., \& Zaman, M. (2012, March). Regulating audit quality: Restoring trust and legitimacy. In Accounting forum (Vol. 36, No. 1, pp. 51-61). Taylor \& Francis.

Kurniawan, R. (2017). Effect of environmental performance on environmental disclosures of manufacturing, mining and plantation companies listed in Indonesia stock exchange. Arthatama Journal of Business Management and Accounting, 1(1), 6-17.

Marfiana, N., \& Kurniasih, L. (2013). Pengaruh karakteristik pemerintah daerah dan hasil pemeriksaan audit BPK terhadap kinerja keuangan pemerintah daerah kabupaten/kota. Sustainable Competitive Advantage (SCA), 3(1).

Martani, D., \& Fitriasari, D. (2014). Financial and performance transparency on the local government websites in Indonesia. Journal of Theoretical \& Applied Information Technology, 60(3).

Mustikarini, W. A., \& Fitriasari, D. (2012). Pengaruh karakteristik pemerintah daerah dan temuan audit BPK terhadap kinerja pemerintah daerah kabupaten/kota di Indonesia tahun anggaran 2007. Simposium Nasional Akuntansi XV: Banjarmasin.

Ningsih, S. (2012). The Antecedents of Non-Unqualified Opinions of Local Governments Financial Statements: A Study on Counties and Cities in East Java Province. Asian Journal of Accounting Research, 1(1), 16-27.

Pamungkas, B., Ibtida, R., \& Avrian, C. (2018). Factors influencing audit opinion of the Indonesian municipal governments' financial statements. Cogent Business \& Management, 5(1), 1540256.

Power, M. K. (2003). Auditing and the production of legitimacy. Accounting, Organizations and Society, 28(4), 379-394.

Schneider, M., \& Damanpour, F. (2002). Public choice economics and public pension plan funding: An empirical test. Administration \& Society, 34(1), 57-86.

Suchman, M. C. (1995). Managing legitimacy: Strategic and institutional approaches. Academy of Management Review, 20(3), 571-610.

Suranta, S., Bandi, H. D. P., \& Syafiqurrahman, M. (2018). Financial Performance Analysis of Local Government: Comparative Study of Central Java and South Kalimantan Provinces. Paper presented at International Conference on Finance, Management and Business.

Susilo, D. E. (2018). The Effects of Corporate Social Responsibility on Corporate Value. Arthatama Journal of Business Management and Accounting, 2(1), 14-26.

Suwanda, D. (2015). Factors affecting quality of local government financial statements to get unqualified opinion (WTP) of audit board of the Republic of Indonesia (BPK). Research Journal of Finance and Accounting, 6(4), 139-157.

Whittle, A., Carter, C., \& Mueller, F. (2014). 'Above the fray': Interests, discourse and legitimacy in the audit field. Critical Perspectives on Accounting, 25(8), 783-802. 